\title{
Article/Artigo
}

\section{Active surveillance of American tegumentary leishmaniasis in endemic areas in rural Bolivia}

\section{Vigilância ativa da leishmaniose tegumentar americana em áreas endêmicas na Bolívia}

\author{
Vladimir Luna Tedesqui ${ }^{1}$, Guido Noel Chuquimia Calleja ${ }^{2}$, Rolando Parra ${ }^{3}$, Javier Palacios Pabón ${ }^{4}$, \\ Márcio Neves Bóia ${ }^{1}$ and Filipe Anibal Carvalho-Costa ${ }^{1}$
}

\begin{abstract}
Introduction: American tegumentary leishmaniasis (ATL), including mucocutaneous leishmaniasis (MCL) and localized cutaneous leishmaniasis (LCL), is endemic in Bolivia. We describe the results of active surveillance of ATL from 2001 to 2006 and assess demographic data related to ATL epidemiology in the Yungas valleys. Methods: Community-based active ATL surveillance was performed by the institutions SERVIR, CÁRITAS, and the Health Services Department of La Paz, whose files were reviewed retrospectively. A cross-sectional survey was carried out to assess demographic data in two communities. Results: Two thousand nine hundred nine cases of ATL were detected from 2001 to 2006: 2,488 (85.5\%) corresponded to LCL and 421 (14.5\%) to MCL. A reduction in the proportion of mucosal cases was observed between 2001 and 2006. The proportion of MCL cases increased with age and was higher among males $(15.5 \%$ versus $12.1 \%, \mathrm{p}=0.018)$. The rate of positivity via direct observation of the parasite in dermal scrapings and in parasite cultivation was significantly higher for LCL than for MCL ( $<<0.001$ and $\mathrm{p}=0.009$, respectively). The rate of reactivity in the leishmanin skin test was higher in the group with mucosal lesions $(\mathrm{p}=0.012)$. The cross-sectional survey showed that $40 \%$ of the families had emigrated from the Altiplano. Conclusions: It is necessary to undertake continuous case detection of ATL in the area, where the disease presents a high rate of mucosal cases. Increasing incidence seems to be associated with immigration and continuous deforestation to expand the crop-growing areas.
\end{abstract}

Keywords: American tegumentary leishmaniasis. Surveillance. Bolivia. Treatment. Diagnosis.

\section{RESUMO}

Introdução: A leishmaniose tegumentar americana (LTA), incluindo a leishmaniose mucocutânea (LMC) e a leishmaniose cutânea (LC), é endêmica em várias regiões da Bolívia. Descreve-se um sistema de vigilância da LTA conduzido entre 2001 e 2006 e avaliando-se dados demográficos relacionados à epidemiologia da doença. Métodos: $\mathrm{O}$ sistema de busca ativa foi realizado conjuntamente pelas instituições SERVIR e CÁRITAS e pelo Servicio de Salud de $\mathrm{La} \mathrm{Paz}$ (SEDES), cujos arquivos foram revisados, retrospectivamente. Um estudo transversal foi realizado em duas comunidades para aquisição de dados sócio-demográficos. Resultados: Dois mil novecentos e nove casos de LTA, sendo 2.488 (85,5\%) de LC e 421 (14,5\%) de LMC foram diagnosticados de 2001 a 2006. Foi observada redução na proporção de casos mucosos ao longo do período. A proporção de LMC aumentou proporcionalmente à idade dos pacientes, sendo mais frequente entre pessoas do sexo masculino $(15,5 \%$ versus $12,1 \%, p=0,018)$. A taxa de detecção do parasita nos raspados cutâneos e no cultivo foram significativamente maiores em pacientes com $L C$ do que em pessoas com LMC ( $p<0,001 \mathrm{e} p=0,009$ respectivamente). A reatividade à reação de Montenegro foi mais frequente em pessoas com LMC $(\mathrm{p}=0.012)$. O estudo transversal mostrou que $40 \%$ das famílias nas comunidades estudadas emigraram do Altiplano. Conclusões: Faz-se necessária uma contínua busca ativa de casos de LTA na região, onde a doença é hiperendêmica. As elevadas taxas de incidência parecem estar relacionadas à imigração e ao desflorestamento para expansão das áreas cultivadas.

Palavras-chaves: Leishmaniose tegumentar americana. Vigilância. Bolívia. Tratamento. Diagnóstico.

1. Instituto Oswaldo Cruz, Fundação Oswaldo Cruz, Rio de Janeiro, RJ. 2. Departamento de Salud de La Paz, Bolivia. 3. Proyecto Obras Sociales de Caminos de Acceso Rural, La Paz, Bolivia. 4. Servicios Educativos, La Paz, Bolivia.

Address to: Dr. Filipe Anibal Carvalho-Costa. Laboratório de Sistemática Bioquímica/IOC/FIOCRUZ. Av. Brasil 4365/sala 308, Pavilhão Leônidas Deane, 21040-900 Rio de Janeiro, RJ, Brasil. Phone: $55213865-8182$

e-mail: guaratiba@ioc.fiocruz.br

Received in 01/04/2011

Accepted in 29/07/2011

\section{INTRODUCTION}

American tegumentary leishmaniasis (ATL), including mucocutaneous leishmaniasis (MCL) and localized cutaneous leishmaniasis (LCL), is an endemic vector-borne parasitic disease in rural Bolivia, where it has been documented since preColumbian times ${ }^{1}$ and represents a major public health concern ${ }^{2}$. In Latin America, Bolivia has the highest incidence of ATL, reaching 33 cases per 100,000 inhabitants as reported in $2006^{3}$.

The main etiological agents of ATL in Bolivia are Leishmania (Viannia) braziliensis ( $85 \%$ cases) and Leishmania (Leishmania) amazonensis, although Leishmania (Viannia) lainsoni has also been isolated from patients ${ }^{49}$. As recently reviewed by García et al. ${ }^{3}$, 86 Lutzomyia species occur in Bolivia, of which five are recognized as ATL vectors: $\mathrm{Lu}$. carrerai, $\mathrm{Lu}$. Llanosmartinsi, and $\mathrm{Lu}$. yucumensis are vectors of L. (V.) braziliensis; Lu. nuneztovari anglesi is vector of $L$. (V.) braziliensis, L.(L.) amazonensis, and L. (V.) lainsoni; and Lu. shawi transmits L. (V.) braziliensis. Furthermore, the species $L u$. ayrozai, $L u$. flaviscutellata, and $L u$. neivai are potential vectors of ATL based on eco-epidemiological and behavioral pieces of evidence ${ }^{3}$, while $L u$. longipalpis has been incriminated as vector of L. (L.) infantum [syn. L. (L.) chagasi], the etiological agent of visceral leishmaniasis ${ }^{4}$ in the Yungas region.

In Bolivia, where a high proportion (about 20\%) of the cases exhibit mucosal lesions ${ }^{3,10}$, ATL extends to the majority of tropical lowlands, including the Yungas valley in the sub-Andean region of the Department of La Paz ${ }^{11-13}$. Currently, seven of the country's nine administrative departments are endemic to $\mathrm{ATL}^{3}$. Furthermore, the disease seems to have been introduced recently into some Bolivian rural regions ${ }^{14}$. Here, we describe epidemiological and clinical data from a documentation of 2,909 cases of ATL in the provinces of Sur Yungas, Nor Yungas, and Caranavi, in the Department of La Paz, Bolivia. The initiative aimed to provide access to ATL diagnosis and treatment in well-recognized endemic areas. Furthermore, we present some demographic data related to ATL epidemiology in two communities in the province of Sur Yungas. 


\section{METHODS}

\section{Setting}

The surveillance area comprised the municipalities of Palos

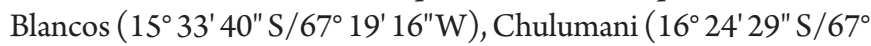
$\left.31^{\prime} 16^{\prime \prime} \mathrm{W}\right)$, La Asunta ( $\left.16^{\circ} 05^{\prime} 30^{\prime \prime} \mathrm{S} / 67^{\circ} 12^{\prime} 00^{\prime \prime} \mathrm{W}\right)$, Irupana $\left(16^{\circ}\right.$ $\left.28^{\prime} 09^{\prime \prime} \mathrm{S} / 67^{\circ} 25^{\prime} 49^{\prime \prime} \mathrm{W}\right)$, and Yanacachi ( $\left.16^{\circ} 23^{\prime} 0^{\prime \prime} \mathrm{S} / 67^{\circ} 44^{\prime} 0^{\prime \prime} \mathrm{W}\right)$ in the province of Sur Yungas; Coripata ( $\left.16^{\circ} 18^{\prime} 32^{\prime \prime} \mathrm{S} / 67^{\circ} 36^{\prime} 19^{\prime \prime} \mathrm{W}\right)$ in the province of Nor Yungas; and Caranavi ( $15^{\circ} 49^{\prime} 31^{\prime \prime} \mathrm{S} / 67^{\circ} 34^{\prime}$ $27 \mathrm{~W}$ W) in the province of Caranavi.

Although the altitude of the Yungas region ranges all the way from $300 \mathrm{~m}$ to $4,000 \mathrm{~m}$ above sea level, most of the region has an altitude between $1,500 \mathrm{~m}$ and $2,400 \mathrm{~m}$. The Yungas Valley extends from the Bolivia-Peru border south-east into central Bolivia and receives excessive rainfall; therefore, the climate is warm and humid. Although the Yungas region is isolated and very difficult to access, this region assumed economic importance in the early $20^{\text {th }}$ century as a major source of citric fruits, sugar cane, coffee, rubber, and coca, attracting many migrants from the economically impoverished Altiplano.

\section{The campaign: case definition and diagnostic procedures}

From January 2001 to December 2006, community-based active ATL surveillance was performed by the institutions SERVIR (a Bolivian non-governmental organization), CÁRITAS (a Catholic Bolivian institution), and SEDES (the Health Services Department of La Paz), which were responsible for diagnosis and treatment of ATL in the area and whose files were reviewed retrospectively.

A health services team composed of doctors and nurses visited all studied municipalities. In Bolivia, a case of ATL was defined by clinical and/or laboratorial criteria. No standardized procedure for case definition (inclusion criteria) was performed. Diagnostic procedures included: I) direct observation of the parasite in dermal scrapings $(\mathrm{n}=2,474)$; II) parasite cultivation $(\mathrm{n}=166)$; III) histopathology $(\mathrm{n}=27)$; IV) leishmanin skin test $(\mathrm{n}=1,466)$; $\mathrm{V})$ serology through indirect immunofluorescence or ELISA $(\mathrm{n}=130)$; and VI) polymerase chain reaction (PCR) $(\mathrm{n}=24)$.

In addition, a cross-sectional survey carried out in January 2006 aimed to assess demographic data in the rural communities of Chimasi and Pastopata (population $=522$ and 775 habitants, respectively), situated in the municipality of Chulumani in the province of Sur Yungas.

\section{Ethical considerations}

This study was approved by the Health Services Department (SEDES) of La Paz, Bolivia.

\section{RESULTS}

The active surveillance detected 2,909 cases of ATL [2,488 (85.5\%) LCL, 421 (14.5\%) MCL], of which 2,643 [2,258 (85.4\%) LCL, 385 (14.6\%) MCL] were treated. In 496 (18\%) patients, only clinical criteria were utilized to diagnose ATL; from these, 228 were submitted to microscopic examination of parasites in scrapings of lesions, the technique proving negative, and 436 were submitted to the Montenegro reaction, which also proved negative. From 2,398 (82\%) patients with some laboratorial evidence of ATL, 1,398 (58\%) presented a positive direct observation of the parasite in dermal scrapings, 861 (36\%) presented only a positive Montenegro reaction, $26(1 \%)$ presented a positive histopathological analysis through biopsy, and $113(5 \%)$ had serological evidence of leishmaniasis through indirect immunofluorescence and/or ELISA tests. In 15 patients, the information was not available. The annual distribution of the cases and the incidence rates are presented in Figures $\mathbf{1}$ and 2, respectively. A statistically significant reduction in the proportion of mucosal cases was observed ( $\mathrm{p}<0.001$, test for linear trend) between 2001 and 2006. As presented in Table 1, the proportion of MCL cases rose with age, reaching $27 \%$ in patients older than 65 years $(\mathrm{p}<0.001$, test

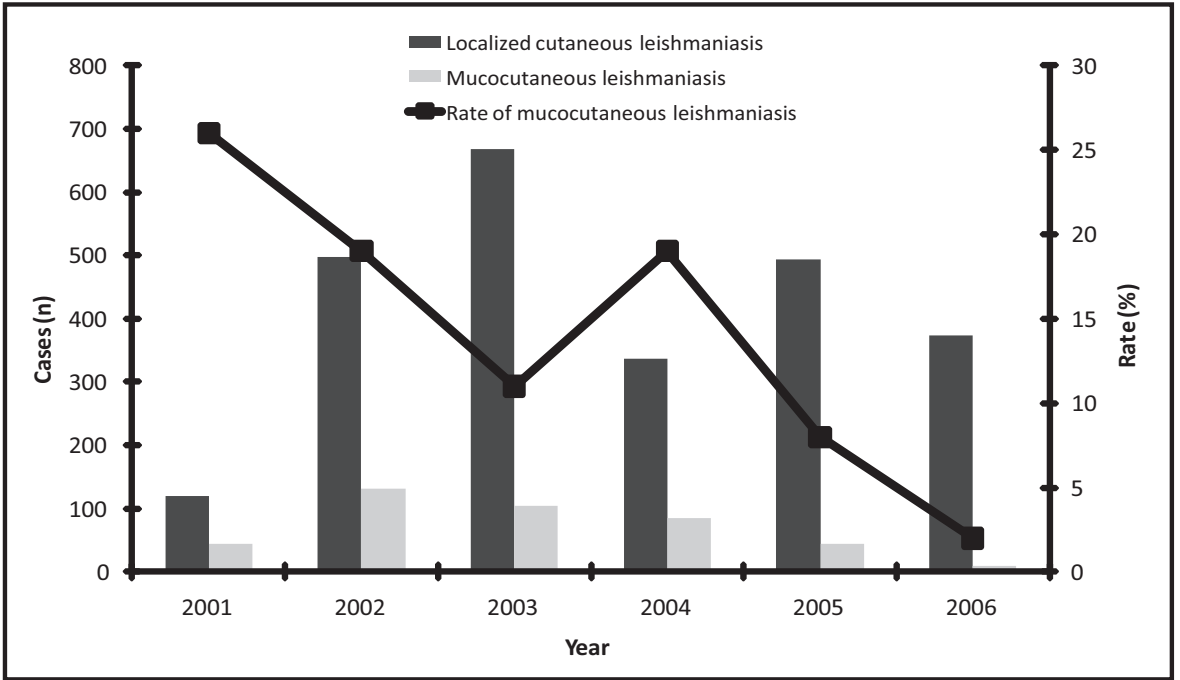

FIGURE 1 - Numbers of localized cutaneous leishmaniasis and mucocutaneous leishmaniasis cases and rates of mucocutaneous cases in the provinces of Sur Yungas, Nor Yungas, and Caranavi, Bolivia, 2001-2006. 


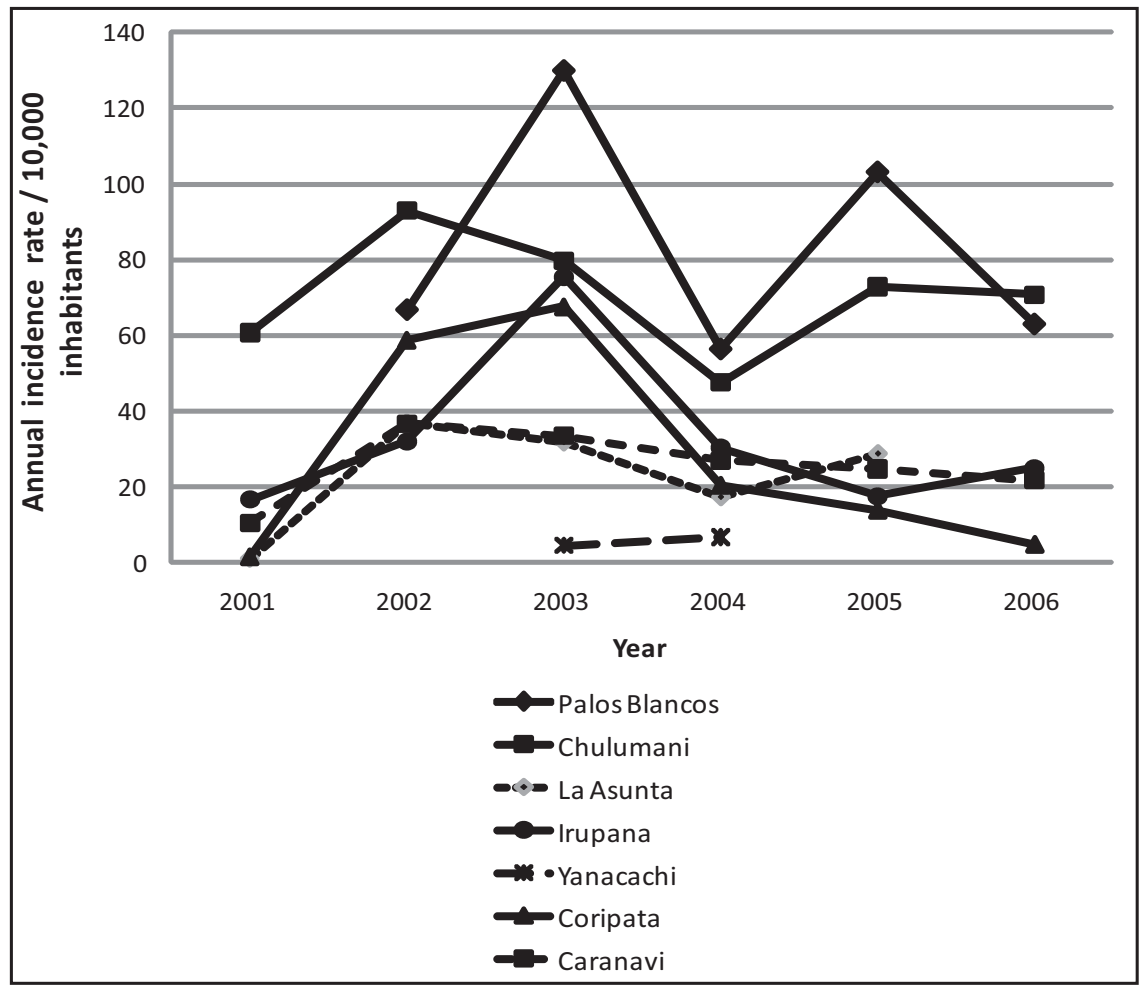

FIGURE 2 - Annual incidence rates of American tegumentary leishmaniasis in seven municipalities in the provinces of Sur Yungas, Nor Yungas, and Caranavi, Bolivia, 2001-2006.

TABLE 1 - Clinical and epidemiological data from 2,909 patients with American tegumentary leishmaniasis surveyed in Bolivia, 2001-2006.

\begin{tabular}{|c|c|c|c|c|c|}
\hline & \multicolumn{2}{|c|}{$\begin{array}{c}\text { Localized cutaneous } \\
\text { leishmaniasis }\end{array}$} & \multicolumn{2}{|c|}{$\begin{array}{c}\text { Mucocutaneous } \\
\text { leishmaniasis }\end{array}$} & \multirow[b]{2}{*}{$\mathbf{p}$} \\
\hline & $\mathbf{n}$ & $\%$ & $\mathbf{n}$ & $\%$ & \\
\hline \multicolumn{6}{|l|}{ Age group (years) } \\
\hline$<1$ & 37 & 100.0 & 0 & 0.0 & \multirow{7}{*}{$<0.001^{\mathrm{a}}$} \\
\hline $1-5$ & 273 & 99.6 & 1 & 0.4 & \\
\hline $6-14$ & 510 & 92.0 & 43 & 8.0 & \\
\hline $15-21$ & 481 & 90.0 & 51 & 10.0 & \\
\hline $22-40$ & 763 & 82.0 & 169 & 18.0 & \\
\hline $41-64$ & 367 & 75.0 & 125 & 25.0 & \\
\hline$>65$ & 57 & 64.0 & 32 & 36.0 & \\
\hline \multicolumn{6}{|l|}{ Gender $n(\%)$} \\
\hline male & 1,708 & 84.5 & 313 & 15.5 & $0.018^{\mathrm{b}}$ \\
\hline female & 780 & 87.8 & 108 & 12.1 & \\
\hline Laboratory evaluation positive/performed & \multicolumn{5}{|c|}{ (\% positive) } \\
\hline direct observation of the parasite in dermal scrapings & $1,315 / 2,145$ & 61.0 & $74 / 329$ & 22.0 & $<0.001^{b}$ \\
\hline parasite cultivation & $97 / 144$ & 67.0 & $9 / 22$ & 40.0 & $0.016^{\mathrm{b}}$ \\
\hline histopathology (biopsy) & $13 / 14$ & 93.0 & $13 / 13$ & 100.0 & $1.00^{\mathrm{c}}$ \\
\hline leishmanin skin test (Montenegro reaction) & $972 / 1,126$ & 86.0 & $318 / 340$ & 94.0 & $0.012^{b}$ \\
\hline indirect immunofluorescence & $46 / 52$ & 88.0 & $49 / 56$ & 87.0 & $0.45^{b}$ \\
\hline ELISA & $10 / 12$ & 83.0 & $8 / 10$ & 80.0 & $1.00^{\mathrm{c}}$ \\
\hline PCR & $7 / 7$ & 100.0 & $16 / 17$ & 94.0 & $1.00^{\mathrm{C}}$ \\
\hline \multicolumn{6}{|l|}{ Treatment } \\
\hline N-methyl-glucamine antimoniate (Glucantime ${ }^{\circledR}$ ) & 2,189 & 89.0 & 282 & 11.0 & \\
\hline amphotericin B & 6 & 5.7 & 99 & 94.3 & \\
\hline sodium stibogluconate (Pentostam ${ }^{\circledR}$ ) & 47 & 92.2 & 4 & 7.8 & \\
\hline miltefosine & 16 & 100.0 & 0 & 0.0 & \\
\hline
\end{tabular}


for linear trend); in addition, the proportion of MCL cases was also higher among males than in females ( $15.5 \%$ vs. $12.1 \%, \mathrm{p}=0.018$, Chi-square test).

Concerning diagnosis, the rate of positivity in the direct observation of the parasite in dermal scrapings and in parasite cultivation was significantly higher for LCL than for MCL ( $p<0.001$ and $\mathrm{p}=0.009$ [Chi-square test], respectively).

A histopathological diagnosis was performed in only 27 (0.9\%) patients, which proved positive (presence of compatible inflammatory infiltrates or intracytoplasmic corpuscles suggestive of Leishmania) in 13/14 LCL and 13/13 MCL cases.

Table 1 shows that rate of reactivity in the leishmanin skin test was higher in the group with mucosal lesions ( $\mathrm{p}=0.012$, Chi-square test).

Among patients with LCL, 2,189 were treated with N-methylglucamine antimoniate (Glucantime $\left.{ }^{\circledR}\right)$, and 47 received sodium

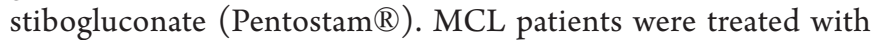
Glucantime ${ }^{\circledR}(n=282)$, Amphotericin $B(n=99)$, or Pentostam ${ }^{\circledR}(n=4)$. Miltefosine was also utilized to treat sixteen patients (Table 1).

The anatomical distribution of the LCL lesions was as follows: $48.3 \%$ in the head/neck, $25.8 \%$ in the lower limbs, $19.4 \%$ in the upper limbs, and $6.6 \%$ in the trunk.

The cross-sectional survey showed that $40 \%$ of the families had emigrated from the Altiplano highlands, with 30\% emigrating in the past eight years (Table 2). A majority of the surveyed dwellers were familiar with the sandflies (quechichos) and were accustomed to seeing them in the plantations.

TABLE 2 - Demographic characteristics of 82 families surveyed in the communities of Chimasi $(n=45)$ and Pastopata $(n=37)$, Chulumani, Department of La Paz, Bolivia, 2006.

\begin{tabular}{|c|c|c|}
\hline Characteristics & Number & Percentage \\
\hline \multicolumn{3}{|l|}{ Origin } \\
\hline highlands (altiplano) & 30 & 39.5 \\
\hline lowlands (tropical/subtropical) & 46 & 60.5 \\
\hline \multicolumn{3}{|l|}{ Time since arrival (years) } \\
\hline$\leq 8$ & 18 & 29.5 \\
\hline $9-20$ & 9 & 14.7 \\
\hline$>20$ & 34 & 55.8 \\
\hline \multicolumn{3}{|l|}{ Products cultivated } \\
\hline coca & 22 & 28.2 \\
\hline coca and citric fruits & 29 & 37.2 \\
\hline citric fruits & 27 & 34.6 \\
\hline \multicolumn{3}{|l|}{ Animals in peridomicile } \\
\hline chicken & 56 & 82.3 \\
\hline $\operatorname{dog}$ & 50 & 73.5 \\
\hline cat & 35 & 51.4 \\
\hline mule & 11 & 16.1 \\
\hline horse & 5 & 7.3 \\
\hline pig & 3 & 4.4 \\
\hline goat & 1 & 1.4 \\
\hline rabbit & 1 & 1.4 \\
\hline \multicolumn{3}{|c|}{ Presence of a case of ATL in the family } \\
\hline yes & 22 & 26.8 \\
\hline no & 60 & 63.2 \\
\hline \multicolumn{3}{|c|}{ Locations accustomed to observing sandflies } \\
\hline home & 20 & 25.6 \\
\hline plantings & 63 & 84.7 \\
\hline
\end{tabular}

ATL: American tegumentary leishmaniasis.

\section{DISCUSSION}

In this study, we present the data obtained from a large ATL community-based active surveillance system carried out in the Yungas Valley of sub-Andean Bolivia from 2001 to 2006. We observed that some municipalities presented very high annual incidence rates, reaching 1,300 cases/100,000 habitants in Palos Blancos in 2003. Torres Espejo et al. ${ }^{11}$ compared epidemiological features of ATL in three regions of Bolivia (Alto Beni, Yungas, and Pando). These authors noticed that incidence rates were higher in the Yungas Valley and Alto Beni, consistent with our finding that the Yungas Valley is a highly endemic region.

It has been proposed that ATL occurs in three basic ecoepidemiological patterns: I) in rainforest areas (sylvatic), affecting people involved in gathering activities; II) in agricultural areas, which are contiguous to primary forests, affecting farmers; and III) in periurban areas, affecting people living at the periphery of cities ${ }^{15}$. Here, we demonstrated that the transmission of ATL in the studied region appeared to be related to agricultural activities in a geographical scenario where planting zones are situated close to the forest and continuous deforestation is carried out to expand the crop-growing areas.

Although the epidemiological transmission profile of ATL in Bolivia has traditionally been associated with sylvatic cycles or with regions contiguous with forested areas (in the context of farm expansion), it has been suggested that, in some Bolivian regions, the transmission profile has been changing towards one of domestication ${ }^{16}$. The presence of Lu. nuneztovari anglesi in domestic and peridomestic environments in sub-Andean Cajuta and Yungas points to the possibility of domestic transmission of L. (L.) amazonensis e L. (L.) braziliensis in these two regions ${ }^{16-17}$.

In this study, many cases were observed in children, suggesting recent parasite transmission. The occurrence of LTA in children under the age of five years $(n=310)$ could be explained by two hypotheses: I) domestic/peridomestic transmission, or II) transmission in rural areas. In support of the first hypothesis, it is known that phlebotomines have nocturnal habits and diurnal transmission is mainly associated with sylvatic environments.

Regarding the temporal distribution of mucocutaneous and localized cutaneous leishmaniasis, a very high MCL: LCL ratio (1:3) was observed in the first year of the campaign. This ratio was reduced to $1: 37$ after five years, suggesting that poor access to health services may be a determinant of the high proportion of mucosal lesions that has been reported in Bolivia ${ }^{18}$. As reviewed by Garcia et al. ${ }^{3}$, other factors that could explain the unusually high MCL: LCL ratio observed in the studied area include host ethnicity and immunogenetics, virulence of specific parasite strains, and the molecular composition of the saliva of local sandfly vectors. In Bolivia, parasitological studies designed to trace the etiological profile of ATL revealed the predominance of the species $L$. (V.) braziliensis. The association of this species of Leishmania with cases presenting compromised mucosa ${ }^{19}$ could also contribute to the high proportion of MCL cases observed in the initial period of the treatment campaign. We also observed that the number of cases with compromised mucosa rose significantly as age bracket increased, and we infer that the degree of mucosal damage is directly related to the subject's age, suggesting that mucosal damage occurs progressively. Regarding distribution between the sexes, we observed that a 
significant proportion of mucosal cases occurred in male patients. Furthermore, almost $70 \%$ of the total of ATL cases observed in the region occurred in male patients. We speculate that the higher rates of Leishmania infection in males could be related either to their higher risk of exposure during traditionally male-dominated activities, such as planting and harvesting crops, or to reluctance on the part of males themselves to seek treatment at health care centres in the period prior to this active surveillance. The high rates of mucosal damage and facial deformities associated with ATL reported in this study establish leishmaniasis as a major health problem in the Yungas valley.

The studied municipalities are newly colonized zones that receive populations from the economically impoverished Andean highlands (Altiplano), seeking improved living conditions through agricultural activities. This is illustrated by the significant population growth that was observed in La Asunta (81.9\%), Palos Blancos (34.8\%), Chulumani (23.6\%), and Caranavi (24.1\%) between 1992 and 2006, according to the estimate given by the National Institute of Statistics of Bolivia ${ }^{20}$.

The cross-sectional survey was carried out in two typical communities in the province of Sur Yungas, with the aim of evaluating demographic and socio-economic variables. We observed that a high proportion of the population has been residing in the region for less than eight years and that many of these new residents have come from the Altiplano. Furthermore, the majority of these families are engaged in agricultural activities. These data support the hypothesis that the current hyper-endemic levels of ATL in the Yungas could be related to the expansion of farms. This expansion is often accompanied by deforestation and/or the transfer of labor activities into the neighboring woods, both of which disrupt natural habitats of Leishmania. This study, therefore, highlights the need to undertake continuous case detection of ATL in the Yungas valley.

\section{ACKNOWLEDGMENTS}

The authors thank the Bolivian institutions Servicios Educativos (SERVIR), SEDES, and CÁRITAS for giving permission to access their files.

\section{CONFLICT OF INTEREST}

The authors declare that there is no conflict of interest.

\section{FINANCIAL SUPPORT}

Active leishmaniasis surveillance was carried out by SERVIR, La Paz, Bolivia; CÁRITAS; and SEDES (the Health Services Department of La Paz). This study comprises part of the work towards a Master's Degree in Tropical Medicine in the Oswaldo Cruz Institute/Oswaldo Cruz Foundation for V.L. Tedesqui.

\section{REFERENCES}

1. Altamirano-Enciso AJ, Marzochi MCA, Moreira JS, Schubach AO, Marzoch KBF. On the origin and spread of cutaneous and mucosal leishmaniasis, based on pre- and post-Colombian historical sources. Hist Cienc Saude 2003; 10:853-882.

2. Davies CR, Reithinger R, Campbell-Lendrum D, Feliciangeli D, Borges R, Rodriguez N. The epidemiology and control of leishmaniasis in Andean countries. Cad Saude Publica 2000; 16:925-950.
3. García AL, Parra R, Rojas E, Delgado R, Dujardin JC, Reithinger R. Leishmaniasis in Bolivia: comprehensive review and current status. Am J Trop Med Hyg 2009; 80:704-711.

4. Le Pont F, Desjeux P. Leishmaniasis in Bolivia. I. Lutzomyia longipalpis (Lutz \& Neiva, 1912) as the vector of visceral leishmaniasis in Los Yungas. Trans R Soc Trop Med Hyg 1985; 79:227-231.

5. Espejo JM, Pratlong F, Le Pont F, Mouchet J, Desjeux P, Rioux JA. Leishmaniasis in Bolivia. V. Human strains of Leishmania (V.) braziliensis from the Department of Pando. Mem Inst Oswaldo Cruz 1989; 84:583.

6. Le Pont F, Desjeux P. Leishmaniasis in Bolivia. II. The involvement of Psychodopygus yucumensis and Psychodopygus llanosmartinsi in the selvatic transmission cycle of Leishmania braziliensis braziliensis in a lowland subandean region. Mem Inst Oswaldo Cruz 1986; 81:311-318.

7. Martínez E, Le Pont F, Torrez M, Tellería J, Vargas F, Muñoz M, et al. A new focus of cutaneous leishmaniasis due to Leishmania amazonensis in a Sub Andean region of Bolivia. Acta Trop 1998; 71:97-106.

8. Martinez E, Le Pont F, Mollinedo S, Cupolillo E. A first case of cutaneous leishmaniasis due to Leishmania (Viannia) lainsoni in Bolivia. Trans R Soc Trop Med Hyg 2001; 95:375-377.

9. Bastrenta B, Buitrago R, Vargas F, Le Pont F, Torrez M, Flores M, et al. Firs evidence of transmission of Leishmania (Viannia) lainsoni in a Sub Andean region of Bolivia. Acta Trop 2002; 83:249-253.

10. David C, Dimier-David L, Vargas F, Torrez M, Dedet JP. Fifteen years of cutaneous and mucocutaneous leishmaniasis in Bolivia: a retrospective study. Trans R Soc Trop Med Hyg 1993; 87:7-9.

11. Torres Espejo JM, Le Pont F, Mouchet J, Desjeux P, Richard A. Epidemiology of cutaneous leishmaniasis in Bolivia. 1. Description of study zone and prevalence of the disease. Ann Soc Belg Med Trop 1989; 69: 297-306.

12. Le Pont F, Mouchet J, Desjeux P, Torres Espejo JM, Richard A. Epidemiology of cutaneous leishmaniasis in Bolivia. 2. Transmission patterns. Ann Soc Belg Med Trop 1989; 69:307-312.

13. Dedet JP, Melogno R, Cardenas F, Valda L, David C, Fernandez V, et al. Rural campaign to diagnose and treat mucocutaneous leishmaniasis in Bolivia. Bull World Health Org 1995; 73: 339-345.

14. Rojas E, Parra R, Delgado R, Reithinger R, Garcia AL. Leishmaniasis in Chaparé, Bolivia. Emerg Infect Dis 2009; 15:678-680.

15. Kawa H, Sabroza PC. Spatial distribution of tegumentary leishmaniasis in the city of Rio de Janeiro. Cad Saude Publica 2002; 18:853-865.

16. Martinez E, Le Pont F, Torrez M, Telleria J, Vargas F, Dujardin JC, et al. Lutzomyia nuneztovari anglesi (Le Pont \& Desjeux, 1984) as a vector of Leishmania amazonensis in a sub-Andean leishmaniasis focus of Bolivia. Am J Trop Med Hyg 1999; 61:846-849.

17. Torrez M, Lopez M, Le Pont F, Martinez E, Munoz M, Hervas D, et al. Lutzomyia nuneztovari anglesi (Diptera: Psychodidae) as a probable vector of Leishmania braziliensis in the Yungas, Bolivia. Acta Trop 1998; 71:311-316.

18. Dimier-David L, David C, Munoz M, Vargas F, Bustillos R, Valda L, et al. Epidemiological, clinical and biological features of mucocutaneous leishmaniasis in Bolivia after a 221 patient sample. Bull Soc Pathol Exot 1993; 86:106-111.

19. Amato VS, Tuon FF, Bacha HA, A Neto V, Nicodemo AC. Mucosal leishmaniasis. Current scenario and prospects for treatment. Acta Trop 2008; 105:1-9.

20. Instituto Nacional de Estadística, Bolivia 2002. Estimaciones y proyecciones de población, periodo 1950-2050; La Paz (Bolivia); Serie OI No. 202; p. 1-58. 